\title{
Evaluation of Sentinel Events And Suicide Predictors in X Magelang Hospital
}

\section{Edi Yusuf*}

*Correspondent Author: ediyusuf.1966@gmail.com

*Prof Dr Soerojo Mental Hospital Magelang, Central Java, Indonesia

\begin{tabular}{l}
\hline I N D E X I N G \\
\hline Keywords: \\
Sentinel; \\
suicide, \\
Mental disorders
\end{tabular}

\begin{tabular}{l}
\hline A B S T R A C T \\
\hline Sentinel events can result in death in suicide cases perpetrated by patients with mental disorders. The \\
research was conducted using qualitative method. Themes obtained through coding the results of \\
interviews, Predictor factor of sentinel events suicide are first: work culture of health workers, \\
second: not optimised of human resources health workers, third: not obedient of SPO patient safety \\
by officers, fourth: facilities and infrastructure of mental hospitals that support the case Sentinel \\
suicide, and depression conditions in patients led to a suicide sentinel case. Prevention strategies for \\
suicide sentinel cases include: preliminary early assessment of suicidal risk patients, improvement of \\
infrastructure facilities that support patient safety, improvement of human resources quality with \\
education and training
\end{tabular}

Kata Kunci:

Sentinel;

Bunuh diri;

Gangguan jiwa;

\begin{abstract}
Kejadian sentinel dapat mengakibatkan kematian pada kasus bunuh diri yang dilakukan oleh pasien dengan gangguan jiwa. Penelitian dilakukan dengan menggunakan metode kualitatif. Tema yang didapatkan melalui coding hasil wawancara terkait dengan faktor prediktor suicide pada kejadian sentinel yaitu pertama: budaya petugas kesehatan, kedua: jumlah ketenagaan kurang, belum optimalnya SDM Kesehatan, ketiga: ketidakpatuhan SPO patient safety oleh petugas, keempat: sarana dan prasarana rumah sakit jiwa yang mendukung terjadinya kasus sentinel bunuh diri, dan kondisi depresi pada pasien menyebabkan terjadinya kasus sentinel bunuh diri. Strategi pencegahan terjadinya kasus sentinel bunuh diri antara lain: pengkajian awal yang tepat pada pasien resiko bunuh diri, perbaikan sarana prasarana yang mendukung keselamatan pasien, peningkatan kualitas SDM dengan pendidikan dan pelatihan.
\end{abstract}

(C) 2017 JMMR. All rights reserved

Article history: Received 08 Sep 2017; Revised 09 Oct 2017; Accepted 15 Nov 2017

\section{INTRODUCTION}

In patient safety there is an unexpected event (UE), an unexpected number of events occurring in the United States of which about 100,000 deaths occur and $50 \%$ of those deaths can be prevented. Based on data from the Utah Colorado Study (UTCOS) in 1992, the rate of UE in the United States was 5.4\%. While in Australia, the results of Quality in Australian Health Care Study study (QAHCS) showed the percentage of KTD is about $16.6 \%$. While in England data KTD in the year 1999-2000 that is equal to 11,7\%. World Alliance on Patient Safety, 2004. While for sentinel incidence from January 1995 to September 2007 based on Joint Commission data in the United States on 4,693 sentinel incidents, $13.1 \%$ due to misplaced surgery, $12.2 \%$ due to suicide and $11.9 \%$ due to postoperative complications. ${ }^{1}$ Reports of patient safety incidents in Indonesia based on data in each province, in 2007 found the province of DKI Jakarta occupies the highest position that is $37.9 \%$, among the eight other provinces (Central Java 15.9\%, DI Yogyakarta 13.8\%, East Java $11,7 \%$, Aceh 10.7\%, South Sumatra 6.9\%, West Java $2.8 \%$, Bali $1.4 \%$, South Sulawesi $0.7 \%)^{2}$ Central Java ranks second in Java Island.

In the unexpected event there is a sentinel event, according to JCAHO cited by UTMDACC ${ }^{3}$, sentinel event (SE) or sentinel event is an unexpected event that ultimately results in death, severe physical or psychological injury, or risk Which leads to death or the presence of a severe injury. Joint Commission International (2005) defines sentinel events as an unexpected event involving serious physical or psychological death or injury. Particular serious injuries include loss of limb or function. This term is used for very unexpected or unacceptable events. ${ }^{4}$ 
Named with sentinel events because of the need for an immediate investigation and response. Joint Commission International states that sentinel figures are not identical with medical errors. Not all sentinel events are from errors, and not all errors cause sentinel events. So an accredited health organization is needed to determine sentinel events in a consistent way by setting policies to identify, report, and manage sentinel events.

So an accredited health organization is needed to determine sentinel events in a consistent way by setting policies to identify, report, manage sentinel events, and protection Bryan, 2017..$^{5}$ Dynamic sentinel node biopsy provides a means of assessing lymph node status through a minimally invasive procedure. ${ }^{6}$

The results showed that sentinel incidence occurring in mental hospitals was suicide (12.4\%), suicide is a conscious action performed by the patient to end his life. Based on the likelihood of patients committing suicide, we recognize three types of suicidal behavior, namely suicide, suicide and suicide attempts. ${ }^{7}$

Persons in psychiatric or people with mental disorders (ODGJs) are persons who undergo a change in mind, behavior, and feeling disorder that appears in the form of a set of responses or symptoms and significant behavioral changes in ODGJ clients, and may Causing an impact on life and constraints on the client in carrying out its function as a human being. ${ }^{8}$ Mental disorders can make a person unable to perform daily activities and can not make decisions so that clients of mental disorders do not live up to its function. ${ }^{9}$ In this case when a person experiencing mental disorders can be at greater risk to commit suicide due to the change of mind that leads to hallucinations containing commands to commit suicide and the change of feelings of sadness that prolonged so that patients try to end his life by suicide.

Psychiatric inpatients are more at risk of committing suicide than public hospitals shown with previous research results where the psychiatric hospitalization suicide range is $100-400$ per 100,000 patients whereas in the range of suicides in public hospitals is $5-15$ per 100,000 patients. Of 75 sentinel events from two different hospitals between mental hospitals and public hospitals showed that the greatest diagnosis of patients was schizophrenia (50.67\%) followed by bipolar disorder (18.24\%) and depression disorder $(9.33 \%)$, The diagnosis indicates that the patient is mentally ill. ${ }^{9}$

Based on the phenomenon of sentinel events in mental hospitals in particular which can lead to the occurrence of death threats by suicide, it is necessary to conduct an appropriate analysis involving the health team: doctors, nurses and other health workers. Sentinel event analysis needs to be done in order to prevent the occurrence of sentinel events. Based on the phenomenon, researchers are interested to examine the evaluation of sentinel incidence of suicide in mental hospitals.

Based on the results of this study, technically it can be planned follow up at mental hospital related to the tracking of the reported event and improvement of patient safety culture, seen from number of reporting of patient safety incident specially sentinel event in suicide case.

\section{RESEARCH METHOD}

The approach in this research is to use a qualitative research approach. Descriptive qualitative research is a research by method or approach of case study (case study). This study focuses intensively on one particular object that studies it as a case. Case study data can be obtained from all parties concerned, in other words in this study collected from various sources. ${ }^{10}$

The research instrument used is using structured interview guide. Research questions are given using openended questions, so as to extract diverse information from participants. Researchers use interview guidelines as a tool to limit questions so that the discussion is not widened and focused.

Methods of data collection conducted by researchers is by in-depth interviews. Interviews are talks that have goals and are tackled with some informal questions. Interviews aimed at obtaining information from research participants. Researchers conducted interviews by exploring the feelings, perceptions and thoughts of the study participants. ${ }^{11}$

\section{RESULT AND DISCUSSION}

\section{Patient Characteristics at Sentinel Suicide}

Characteristics of patients on suicide sentinel events grouped by sex, age, and medical diagnosis are presented in Table 1.

Table 1. Patient Characteristics At Sentinel Suicide

\begin{tabular}{llrc}
\hline No & \multicolumn{1}{c}{ Category } & Amt & \% \\
\hline 1. & Sex & & \\
& Male & 5 & $83,33 \%$ \\
& Female & 1 & $16,67 \%$ \\
2. & Age (years old) & & \\
& $15-24$ & 1 & $16,67 \%$ \\
& $25-44$ & 2 & $33,33 \%$ \\
\hline
\end{tabular}




\begin{tabular}{|c|c|c|c|}
\hline & $45-65$ & 2 & $33,33 \%$ \\
\hline & $>65$ & 1 & $16,67 \%$ \\
\hline \multirow[t]{8}{*}{3.} & Medical diagnosis & & \\
\hline & Severe depression & 3 & $50,00 \%$ \\
\hline & with psychotic & & \\
\hline & symptoms & & \\
\hline & Severe depression & 2 & $33,33 \%$ \\
\hline & post schizophrenia & & \\
\hline & Paranoid & 1 & $16,67 \%$ \\
\hline & schizophrenia & & \\
\hline
\end{tabular}

Characteristics of patients in the incidence of sentinel suicide in table 1 showed that male sex patients as many as 5 people $(83.33 \%)$, mostly in adults (18-60 years) as many as 5 people $(83.33 \%)$ and medical diagnosis Most patients had severe depression with psychotic symptoms of 3 people $(50.00 \%)$.

The results showed that the suicide rate was higher in women than in men, but in males had a higher rate in the success of ending life, it is because men more use violence and use an effective method of suicide to end life ${ }^{11}$. Some of the suicidal ways committed by men who lead to death include hanging $(60 \%)$, using motor vehicles $(11 \%)$ and firearms $(8 \%){ }^{13}$ Such efforts may eventually lead to successful suicide.

In the age-based characteristics, at most in adulthood, the task of psychosocial development in the adult stage is to have a mature personal identity (physical and psychological) in family, community, and work life that reflects progress and the achievement of an earlier life goal Set. Married, lifestyle changes, having children, having a job, and improving quality of life are subject to careful review. Possible stressors such as career changes (job promotion, layoffs or job changes), changes in family units (death, depression, or psychosomatic disorder. ${ }^{14,15,16} \mathrm{~A}$ greater stressor because when entering the adult stage the responsibility will be greater, where the adult individual is not dependent with others, because it is able to do everything by themselfes.

The results showed that the medical diagnosis of patients in the incidence of sentinel suicide is severe depression with symptoms of psychosis as much as 3 patients $(50.00 \%)$. According to the classification of the diagnosis of PPDGJ III, severe depression criteria are: 1) all 3 major symptoms of depression should be present, 2) plus at least 4 of the other symptoms and some of which must be heavy intensity 3) when there are important symptoms (eg psychomotor retardation) Conspicuous, the patient may be unwilling or unable to report many of his symptoms in detail. In such cases, a thorough assessment of the episodes of severe depression can still be justified. 4) It is highly unlikely that the patient will be able to continue social activities, work or household affairs, except at a very limited level. Severe depression with psychotic symptoms, a symptom of severe depression above, accompanied by delusions, hallucinations or stupor depression. Waham usually involves the idea of sin, poverty or calamity that threatens and the patient feels responsible for it.

\section{Theme Results: Predictor Factors Occurrence of Sentinel Suicide Case at Mental Hospital}

\section{First Theme: Work Culture of health worker}

There is a lack of caution shown by health care workers in the event of a suicide sentinel case. Behavior of health workers during the occurrence of suicide sentinel case one of them is awareness (awareness) in the patient safety ${ }^{17}$, there are three levels of awareness of the situation of the first health care is a perception involving critical attention from the cue in Eg, the patient's vital signs, the symptoms that appear in the patient, the anxiety condition, the voice monitor, then the second is the understanding of what the sign means, for example the nurse should combine the patient's information about the reported symptoms, the readings from the monitor and the charts and reports of other nurses, To understand the current state of the patient's condition. The third level of awareness of the situation is projection or anticipation.

This is a prediction of what will happen to the current task in the near future. The nurse recognizes the combination of warning signs and realizes that the patient will deteriorate within the next few minutes and therefore take action to prevent this. Skills possessed by health workers in this regard are projection, very important in enabling proactive, not reactive response to expected and unexpected events ${ }^{17}$. A good situation alert is essential in all areas of health care, especially in acute treatment, so the incidence of suicide sentinels should be preventable by health personnel.

\section{Second Theme: not optimised of human resources}

There is a lack of manpower during the case of a sentinel suicide in a mental hospital. Inadequate amount of labor causes stress of health workers in mental hospitals, especially nurses, who are in this case for 24 hours to supervise patients and provide appropriate psychotherapy for patients. Health workers on psychiatric services are 
considered as one of the most high-performing workloads, and there is a high risk of job stress involving the physical and psychological health of these personnel. Health workers are required to help others who are physically and mentally involved. ${ }^{18}$

The causes of stress include work relationships between nurses and physicians and other health care professionals, relationships with patients and families, emergency cases, high workload, lack of staff and lack of support or positive feedback from superiors. ${ }^{18}$ Psychiatric nurses have unusual work environments, locked wards, potential patient conflicts with physical and mental hazards associated with aggressive patient behavior and prevent patients from harming themselves. ${ }^{18}$ High stress results in a decrease in job performance, decreased job satisfaction, and quality of care provided to patients.

Third theme: Not obedient of SPO Patient Safety by officers

The third theme that is obtained is not the implementation of SPO by health workers. Sentinel incident suicide can be caused by error factor, which resulted in not implemented SPO patient safety that should be implemented. Errors or errors are done in two categories, namely errors in execution, and the second is a mistake in knowledge that results in patients in unsafe conditions ${ }^{18}$. There are two causes of error, the first is the individual cause, the second is the system. Individual approach is caused by forgetting, or not taking into account the condition of the patient, while the system approach is the condition and the existing system in which the individual works causing the error. ${ }^{20}$ So, mistakes can not only be caused by the individual but also because of the system.

In the implementation of SPO officers pay less attention to SPO and the existing policy in the hospital for the supervision of suicide patients, if the SPO is run fully of course sentinel event of suicide will not happen, suicide sentinel incident also due to lack of oversight due to negligence of officer.

Fourth Theme: The facilities and infrastructure of mental hospitals that support the occurrence of suicide sentinel cases

The facilities and infrastructure of psychiatric hospitals that support the occurrence of suicide sentinel cases. Hospitals and facilities can be used by patients to conduct suicide attempts. The facilities and infrastructure in the hospital should be a comfortable and safe privacy for the patient, the building can form a therapeutic relationship between health and patient personnel, and the room can be a place where nurses can engage and connect with patients by realizing the potential Healing in the patient. ${ }^{21}$

\section{The Fifth Theme: The condition of depression in} patients leads to a suicide sentinel case

Conditions of depression in patients cause a case of sentinel suicide. The results of research that has been done shows that during depressive episodes may increase a person's risk for attempted suicide. ${ }^{22}$ Patients with severe depression with symptoms of psychosis have an unfavorable outcome Schaffer, et al, 2008. So in this study indicate that depressive episodes experienced by the patient to be a factor predictor of suicide.

The results of prospective studies in previous studies showed that in patients who committed suicide other than due to depression is also caused by the delusional or delusional patient that eventually leads someone to attempt self-suicide. Shares can be pursued, or guilty or sinful. ${ }^{23}$

The results of a study showed that in the depression with psychotic condition showed a stronger relationship with the intensity of attempting suicide, the instrument used to assess depression using Hammilton Depression Rating Scale (HDRS) with $\mathrm{p}$ value $<0.05^{22}$. In patients with depression accompanied by psychotic symptoms make it difficult for the patient to communicate thoughts and emotions, thus affecting the lack of ability to convey the existence of suicidal thoughts.

\section{Strategy Prevention Steps Suicide Sentinel Case}

The results of interviews with 5 (five) participants of health workers working in mental hospitals such as specialist doctors or DPJP, patient safety team and nurses, found some steps of prevention strategy of suicide sentinel cases obtained:

First Prevention: Preliminary Pre-liminary Assessment in Suicide Risk patients

Strategies that can be done in the form of accuracy in the assessment of patients with suicidal risk, including the assessment of a history of suicide in a person, because it is closely related to the possibility of patients to repeat suicide, also reviewed the mechanism used to commit suicide $^{23}$. It is also studied about situations that can trigger suicidal thoughts, and sources that can be used in times of crisis situations in patients. 
The risk of suicide occurs in most cases of depression so that at the beginning of admission to the RSJ it is necessary to do a special study on depression for further screening whether the patient is at risk or not committing suicide, starting from the Emergency Installation, and continuous every time there is Transition between rooms or between units, if appropriate assessment will be planned regarding settings in care, therapeutic interventions, and measuring patient safety measures that can be performed. ${ }^{25}$ Health workers should be able to properly assess depression in patients with mental disorders.

\section{Second Prevention: Improvement of infrastructure that supports patient safety}

Environmental modifications are related to the equipment or condition of the room used by the patient to commit suicide by substituting safer ones so that they are no longer used for suicide, eg an anchored grill that can be attributed by the patient to suicide ${ }^{24}$. By replacing or removing risky tools used to commit suicide so it is expected to reduce the number of suicides.

The patient's room should be designed to remove elements of the environment that might facilitate suicide attempts. Reasonable steps should be taken to ensure the care environment is designed to improve patient safety including removing razor sharp objects, electrical appliances, plastics, garbage cans, and insecure windows ${ }^{24}$. Redesign the prevention strategies through door locking mechanisms, patient monitors, and alarms, removing objects that can be used to hang oneself like a belt, shoelace or rope, and a nurse station near a patient who has a high risk of suicide.

Third Prevention Improving the Quality of Human Resources with Education and Training

Prevention strategies for incidence of sentinel suicide are conducted through education and training. All staff should be educated about risk factors for self-mortality in inpatient and hospital protocols in prevention efforts. Training should include how to be alert to behavioral changes or routines of patients at risk and warning signs that may indicate the need for immediate action to prevent suicide. Training is also linked to the handling of emergency patients in the psychiatric unit and how to perform proper screening in a mental hospital. ${ }^{25}$

Nurses should also be able to observe patients with a strict suicide risk. Observation can be done intermitten or continuously in patients. This can prevent the occurrence of suicide events in patients. ${ }^{24}$ The results showed that performing a good and constant observation pattern in patients with suicidal risk may reduce the risk of patients committing suicide. ${ }^{26}$

\section{CONCLUSION}

1. The identification of sentinel cases in suicidal cases shows that patients on the incidence of suicide sentinel most male sex have a greater tendency to commit suicide, mostly in adulthood and the most common medical diagnosis in cases of sentinel suicide is a severe depression with psychotic symptoms.

2. Predictor factors causing suicide sentinel case at Mental Hospital are: work culture of health officer, secondly: not yet optimal health human resources performance, third: non compliance with SPO patient safety by officer, fourth: facility and infrastructure of Mental Hospital that support the occurrence of suicide sentinel cases, and the condition of depression in patients leads to a case of sentinel suicide.

3. The results of the evaluation related to the prevention strategy steps of suicide sentinel cases include: appropriate initial assessment of suicidal risk patients, improvement of infrastructure facilities that support patient safety, improving the quality of human resources with education and training

\section{ACKNOWLEDGMENT}

\section{Many thanks to:}

1. Dr.dr.Fidiansjah, Sp.KJ., MPH, as the Director of Prevention and Control of Mental Health and Medication Problem of the Directorate General of Disease Prevention and Control of the Ministry of Health, which has motivated the study.

2. dr.Endang Widyaswati, M.Kes, as Director of RSJ.Prof.Dr.Soerojo Magelang which has allowed the continuity of the learning process.

3. Dr.dr.Arlina Dewi, M.Kes., AAK, as Head of Management of Hospital of Muhammadiyah University of Yogyakarta, who has given his attention, suggestion and criticism.

4. Dr.Elsye Maria Rosa, SKM., M. Kep, as a supervising lecturer concurrently member of the examiner team who has given directions, ideas, suggestions and criticism. 5. Dr.dr.Sri Sundari, M.Kes.as chairman of the testing team and Dr.Qurratul Aini, SKG, .M.Kes, as a member of the examiner team for his advice and criticism 
5. Patient safety team and Medical Record Installation RSJ.Prof.Dr.Soerojo Magelang for its data support

6. Arniwati my wife, my two teachers Yusva Yusuf and Azka Ikmal Yusuf, and all my friends of class XII also all those who have given spirit and prayer

\section{REFERENCE}

1. Sorbello, B. (2008) Responding to a sentinel event. American Nurse Today October 2008 Vol. 3 No. 10. Official Journal of ANA

2. KPP RS - PERSI. (2008). laporan insiden keselamatan pasien di Indonesia

3. The Joint Commision International. (2005). Patient safety

4. The Joint Commision International. (2011). Root Cause Analysis in Health Care:Tools and Techniques. Library of Congress Control Number: 2009931192

5. Liang A. Bryan. 2017. Risks of Reporting Sentinel Events. A system for reporting medical errors could be used for lawsuits rather than just for safety purposes. Health Affairs. Volume 19. Number 5.

6. Bin K. Kroona, Simon Horenblasa. Willem Meinhardta. Henk G. van der Poela. Axel Bexa, Harm van Tinterenb, Renato A. Valde's Olmosc, Omgo E. Nieweg. 2005. Dynamic Sentinel Node Biopsy in Penile Carcinoma: Evaluation of 10 Years Experience. European Urology Vol. 47. Page 601606.

7. Chen, LY, Cheng, TS, \& Lin, CH. 2012.Sentinel events and predictors of suicide amonginpatients at psychiatric hospitals. Chenet al. Annals of General Psychiatry2012,11:4 http://www.annals-generalpsychiatry.com/content/11/1/4

8. Keliat, Budi Anna. (2011). Keperawatan Kesehatan Jiwa Komunitas CMHN (Basic Course). Jakarta: EGC.

9. UU Kesehatan Jiwa Nomer 18 tahun 2014

10. WHO. (2013). Preventing Suicide: A Global Imperative. Geneva: Switzerland

11. Nawawi (1997). Metode peneltian di bidang sosial. UGM Press Yogyakarta

12. Afiyanti, Y., Nur Rachmawati, I. (2014). Metodologi Penelitian Kualitatif Dalam Riset Keperawatan. Jakarta: RajaGrafindo Persada.

13. Blumenthal, S. (1992). Suicide and gender. American Psychiatric Press, Washington DC
14. Beaton, S \& Forster, P. (2012). Insights into men's suicide. InPsych | The bulletin of The Australian Psychological Society Limited

15. Stuart, G.W. (2013). Principles and Practice of Psychiatric Nursing. St.Louis Missouri: Mosby

16. Townsend, CM. (2009). Psychiatric mental health nursing Concept of care in evidence base practice. (6th Ed.). Philadelphia: F.A. Davis Company.

17. Varcarolis \& Halter. (2012). Psychiatric nursing clinical guide; assesment tools and diagnosis. Philadelphia : W.B Saunders Co

18. WHO. (2009). Human Factors in Patient Safety Review of Topics and Tools. (C) World Health Organization (WHO), 2009 WHO/IER/PSP/2009.05

19. Zaki, Rania A. (2016). Job Stress and Self- Efficacy among Psychiatric Nursing Working in Mental Health Hospitals at Cairo, Egypt. Journal of Education and Practice ISSN 2222-1735 (Paper) ISSN 2222-288X (Online) Vol.7, No.20, 2016

20. Carayon, P \& Gurses, A. (2008). Chapter 30. Nursing Workload and Patient Safety-A Human Factors Engineering Perspective. https://www.ncbi.nlm.nih.gov/books/NBK2657/pdf/B ookshelf_NBK2657.pdf

21. Oyebode, F. (2006). Clinical errors and medical negligence. Advances in Psychiatric Treatment (2006), vol. 12, 221-227

22. Smith, P \& Millar, M. (2011). The Quiet Room: Improving the Acute Care Psychiatric Environment. https://www.fons.org/Resource/

Documents/Project\%20Reports/PFWhytemansBraeD ec12.pdf

23. Oquendo MA, Currier D, Mann JJ. Prospective studies of suicidal behavior in major depressive and bipolar disorders: what is the evidence for predictive risk factors?. Acta Psychiatr Scand 2006: 114: 151158 All rights reserved DOI: 10.1111/j.16000447.2006.00829.x

24. Schafer, et al. (2008). Correlates of Suicidality Among Patientswith Psychotic Depression. Suicide and Life-Threatening Behavior 38(4) August 2008 $\square 2008$ The American Association of Suicidology

25. Bagley, S. Chapter 26. Identifying Patients at Risk for Suicide: Brief Review (NEW). Making Health Care Safer II: An Updated Critical Analysis of the Evidence for Patient Safety ractices.https://www.ncbi.nlm.nih.gov/books/NBK133 $374 /$ 
26. McBroom, S. (2012). Reducing Inpatient Suicide RiskIn The Hospital Setting. Compass. Vol. 12, Issue 3
27. Janofsky, J. (2009).Reducing Inpatient Suicide Risk:Using Human Factors Analysis to Improve Observation Practices. J Am Acad Psychiatry Law 37:15-24, 2009 